\title{
PENINGKATAN MOTIVASI PELAKSANAAN PERMAINAN KECIL DALAM PEMBELAJARAN PENJAS DI SEKOLAH DASAR NEGERI 18 SUNGAI GERINGGING KABUPATEN PADANG PARIAMAN
}

\section{LUKMAN}

\begin{abstract}
Abstrak
Permainan kecil merupakan salah satu bentuk materi pembelajaran pendidikan jasmani olahraga dan kesehatan di sekolah dasar. Perinainan kecil memimiliki unsur-unsur gerak yang dapat memicu pertumbuhan dan perkembangan siswa. Disamping itu permainan kecil mudah dipahami siswa sehingga mudah diterapkan di sekolah dasar. Aturan yang tidak terlalu rumit, lama permainan dan fasilitas permainan yang bisa dimodifikasi turut membangkitkan keinginan siswa untuk melakukan permainan kecil. Untuk itu dilakukanlah penelitian untuk meilibat sejauh mana motivasi siswa terhadap modifikasi permainan kecil. Penelitian dilakukan terhadap 38 sampel yaitu siswa kelas IV dan Kelas V yang berada di SD Negeri 18 Sungai Geringging Kabupaten Padang Pariaman . Penelitian ini dilakukan dengan penyebaran angket kepada siswa yang terdiri dari lima kategori jawaban yaitu sangat setuju (SS), setuju (S), tidak setuju (TS), dan sangat tidak setuju (STS) terhadap modifikasi permainan kecil. Berdasarkan hasil penelitian yang dilaksanakan di SD Negeri 18 Sungai Geringging Kabupaten Padang Pariaman, didapatkan 5,00\% menyatakan sangat setuju terhadap modifikasi permainan kecil dalam pembelajaran pendidikan jasmani olabraga dan kesehatan, 57,57\% menyatakan setuju terhadap modifikasi perniainan kecil dalam pembelajaran pendidikan jasmani olahraga dan kesehatan, 37,24\% menyatakan tidak setuju terhadap modifikasi permainan kecil dalam pembelajaran pendidikan jasmani olahraga dan kesehatan, dan 0,20\% menyatakan sangat tidak setuju terhadap modifikasi permainan kecil dalam pembelajaran pendidikan jasmani olahraga dan kesehatan.
\end{abstract}

Keyword: Motivasi, permainan kecil, penjas

Copyright (C) 2016 IICET (Padang - Indonesia) - All Rights Reserved Indonesian Institute for Counseling, Education and Theraphy (IICET)

\section{PENDAHULUAN}

Pendidikan jasmani dan kesehatan adalah salah satu mata pelajaran di sekolah dasar. Menurut Kurikulum Tingkat Satuan Pendidikan (2006:702) Pendidikan jasmani olahraga dan kesehatan (Penjaskesorkes) merupakan media untuk mendorong pertumbuhan fisik, perkembangan psikis, keterampilan motorik, pengetahuan dan penalaran, penghayatan nilai-niIai (sikap-mental-emosional-sportivitas-spritualsosial), serta pembiasaan pola hidup sehat yang bermuara untuk merangsang per tumbuhan dan perkembangan kualitas fisik dan psikis yang seimbang.

Seperti mata pelajaran lainnya, Pendidikan jasmani olahraga dan kesehatan (Penjaskesorkes) juga memiliki tujuan tersendiri, seperti yang tertuang dalam KTSP yang secara umum bertujuan untuk mencapai pertumbuhan dan perkembangan siswa. Tujuan pendidikan jasmani dan kesehatan ini tertuang dalam Kurikulum Tingkat Satuan Pendidikan (2006:703) bahwa: "Pendidikan jasmani olahraga dan kesehatan (Penjaskesorkes) bertujuan agar siswa memiliki kemampuan sebagai berikut: 1. Mengembangkan keterampilan pengelolaan diri dalam upaya pengembangan dan pemeliharaan kebugaran jasmani serta pola hidup sehat melalui berbagai aktivitas jasmani dan olahraga yang terpilih, 2. Meningkatkan pertumbuhan fisik dan pengembangan psikis yang lebih baik, 3. Meningkatkan kemampuan dan keterampilan gerak dasar, 4. Meletakkan landasan karakter moral yang kuat melalui internalisasi nilai-nilai yang terkandung di dalam pendidikan jasmani, olahraga dan kesehatan, 5. Mengembangkan sikap sportif, jujur, disiplin, bertanggungjawab, kerjasama, percaya diri dan demokratis, 6. Mengembangkan keterampilan untuk menjaga keselamatan diri sendiri, orang lain dan lingkungan, 7. Memahami konsep aktivitas jasmani dan olahraga di lingkungan yang bersih sebagai informasi untuk mencapai pertumbuhan fisik yang sempurna, pola hidup sehat dan kebugaran, terampil, serta memiliki sikap yang positif'. 
Guru Pendidikan jasmani olahraga dan kesehatan (Penjaskesorkes) di sekolah seharusnya berusaha dengan sebaik mungkin bagaimana agar pembelajaran yang diberikan di lapangan dapat berpengaruh positif terhadap diri siswa. Dalam hal ini pembelajaran penjas dapat meningkatkan kesegaran jasmani, motivasi, pertumbuhan dan perkembangan fisik, perkembangan intelektual. pembentukan kerjasama sosial dan emosional, prestasi belajar, dan kondisi fisik disamping menimbulkan kesenangan, kegembiraan bagi siswa. Pembelajaran yang disajikan hendaknya bagian dari bentuk bermain atau dikenal juga dengan pembelajaran melalui permainan kecil.

Selain itu pendidikan jasmani dan kesehatan mengutamakan aktivitas fisik dan kebiasaan hidup sehat dalam rangka mengembangkan aspek kebugaran jasmani, keterampilan gerak, keterampilan berfikir kritis, keterampilan sosial, penalaran, stabilitas emosional, tindakan moral, pola hidup sehat dan pengenalan lingkungan bersih melalui aktivitas jasmani, olahraga dan kesehatan terpilih yang direncanakan secara sistematis dalam rangka mencapai tujuan pendidikan nasional.

Dalam pembelajarannya, Pendidikan jasmani olahraga dan kesehatan (Penjaskesorkes) memuat berbagai materi yang dapat menunjang kebugaran dan perkembangan serta pertumhuhan siswa. Permainan kecil adalah salah satu bentuk permainan yang dapat diterapkan di sekolah dasar. Menurut Winaryo (2006: 12) permainan kecil merupakan serangkaian permainan yang dirancang untuk meningkatkan kebugaran jasmani siswa. Kemudian Choiri (2008: 4) mengatakan bahwa “.....permainan kecil adalah salah satu bentuk permainan dalam olahraga yang mampu merilekskan otot-otot syaraf".

Permainan kecil di sekolah dasar juga dapat meningkatkan pertumbuhan dan perkembangan fisik maupun mental siswa, mengingat siswa dalam usia sekolah dasar berada dalam masa pertumbuhan fisik, serta perkembangan intelektualnya. Dengan adanya pertumbuhan fisik yang memadai dan perkembangan intelektual yang ideal dapat membantu siswa dalam melakukan interaksi sosial di kalangannya. Permainan kecil memiliki banyak manfaat. Diantaranya manfaat yang didapat yaitu dapat meningkatkan kesegaran jasmani, motivasi, pertumbuhan dan perkembangan fisik, perkembangan intelektual, pembentukan kerjasama sosial emosional. prestasi belajar. Dari kondisi fisik disamping menimbulkan kesenangan, kegembiraan bagi siswa. Begitu pula sarana dan prasarana yang dibutuhkan dalam pemmbelajaran permainan kecil ini tidak memakan biaya yang mahal dan mewah

Narnun kenyataan di dunia pendidikan berlainan dengan apa yang diharapkan, seperti yang peneliti temukan di SD Negeri 18 Sungai Geringging Kabupaten Padang Pariaman. Masih banyak guru yang belum memberikan pembelajaran dalam bentuk rangkaian permainan kecil. Karena kadang kala pembelajaran yang diberikan mulai dari pemanasan sampai kegiatan inti hanya gerakan-gerakan yang sifatnya menoton dan kaku sehingga dapat menimbulkan kebosanan dan kejenuhan bagi siswa. Contohnya Pemanasan yang diberikan berupa peregangan kepala, tangan, pinggang dan kaki. Kemudian setelah itu siswa disuruh lari mengelilingi lapangan dan bahkan langsung kepada kegiatan inti tanpa dibarengi dengan pemanasan. Dalam hal ini siswa yang melakukan gerakan tersebut, adanya unsur keterpaksaan dan bukan dan keinginan diri sendiri.

Berdasarkan latar belakang dan pembatasan masalah, maka masalah dalam penelitian ini dapat dirumuskan sebagai berikut :

1. Bagaimanakah tingkat motivasi siswa Dalam Pembelajaran Pendidikan Jasmani Olahraga dan Kesehatan di Sekolah Dasar Negeri 18 Sungai Geringging Kabupaten Padang Pariaman?

2. Bagaimanakah Peranan Guru Pendidikan Jasmani Olahraga dan Kesehatan melakukan modivikasi Permainan Kecil Dalam Pembelajaran Penjaskes di Sekolah Dasar Negeri 18 Sungai Geringging Kabupaten Padang Pariaman?

Adapun tujuan dan penelitian ini adalah:

1. Untuk mendiskripsikan tingkat motivasi siswa Dalam Pembelajaran Pendidikan Jasmani Olahraga dan Kesehatan di Sekolah Dasar Negeri 18 Sungai Geringging Kabupaten Padang Pariaman.

2. Untuk mendiskripsikan penerapan modivikasi Permainan Kecil dalam Pembelajaran Pendidikan Jasmani Olahraga dan Kesehatan di Sekolah Dasar Negeri 18 Sungai Geringging Kabupaten Padang Pariaman.

Manfaat yang diperoleh dari penelitian ini adalah:

1. Untuk memperbaiki dan meningkatkan efektifitas pelaksanaan pembelajaran penjaskes khususnya di SD Negeri 18 Sungai Geringging Kabupaten Padang Pariaman

2. Untuk penulis yaitu merupakan syarat untuk naik pangkat dari golongan IV/a ke IV/b.

3. Unuk menambah khasanah ilmu pengetahun terutama dalam hal penelitian. Sebagai bahan referensi untuk melakukan penelitian selanjutnya mengenai masalah yang sama pada lembaga yang berbeda. 


\section{METODELOGI PENELITIAN}

Sesuai dengan masalah yang akan diteliti, jenis penelitian yang digunakan adalah metode deskriptif. Metode mi berfungsi untuk melihat, meninjau, mengetahui dan mengungkapkan keadaan apa adanya pada waktu penelitian dilakukan, kemudian hasilnya diolah dalam bentuk angka. Jadi metode ini bertujuan untuk memecahkan masalah yang ada pada masa sekarang dan memberikan gambaran secara umum dikuti dengan mengklasifikasikan serta analisis data. Penelitian ini dilaksanakan pada bulan November sampai dengan Desember 2014, yang bertempat di SDN 18 Sungai Geringging Kabupaten Padang Pariaman.

Populasi dalam penelitian ini adalah seluruh siswa-siswi kelas I dan VI SD Negeri 18 Sungai Geringging Kabupaten Padang Pariaman, yang berjumlah 137 orang.

Sampel dalam penelitian ini adalah bagian dari populasi yang diambil dengan menggunakan cara-cara tertentu. Sehubungan dengan pengambilan sampel menurut Arikunto (1998), mengemukakan bahwa: "suatu persoalan penting yang dihadapi seseorang peneliti adalah bagaimana dapat memperoleh sampel yang mewakili populasi". Penarikan sampel yaitu purposif random sampling dan diambil siswa kelas IV dan V saja karena siswa kelas I sampai dengan kelas III masih sulit memahami dalam pengisian angket serta siswa kelas VI sedang dalam persiapan Ujian Akhir. Sampel penelitian 38 orang

Penelitian ini menggunakan jenis data primer yang diambil secara langsung, melalui penyebaran angket atau kuesioner kepada responden yang menjadi sampel. Sedangkan sumber data dalam penelitian ini adalah siswa-siswa kelas IV dan V SD N 18 Sungai Geringging Kabupaten Padang Pariaman tahun ajaran 2014/2015

Angket ini disusun dengan menggunakan skala likert dengan lima motif jawaban yaitu sangat setuju (SS), Setuju (S), ragu-ragu (R), tidak setuju (TS), dan sangat tidak setuju (STS) atau selalu sering kadang-kadang jarang dan tidak pernah. Setiap butir diberikan skor dengan angka 5 sampai 1 bila pertanyaan angket positif dan sebaliknya skor 1 sampai 5 bila negatif.

Untuk menentukan tingkat motivasi siswa atas pertanyaan penelitian dengan memberikan skor yang diperoleh dan data dibagi dengan skor yang seharusnya dan Skor motivasi siswa yang berupa data kuantitatif dikualifikasikan sebagai berikut:

$$
\begin{aligned}
& 81 \%-100 \%=\text { Sangat baik } \\
& 61 \%-80 \%=\text { Baik } \\
& 41 \%-60 \%=\text { Cukup } \\
& 21 \%-40 \%=\text { Kurang } \\
& 0 \%-20 \%=\text { Kurang sekali } \\
& \text { (Arikunto 1998:57) }
\end{aligned}
$$

\section{Teknik Analisis Data}

Data yang dikumpulkan dalam penelitian mi dianalisis dengan statistik deskriptif dan menggunakan tabulasi frekuensi atau analisa, persentase. Untuk mencari persentase jawaban pada masing-masing indikator serta sub-sub indikator menggunakan persamaan sesuai dengan peryataan Sudjana (1992 : 40) sebagai berikut:

$$
P=\frac{F}{N} \times 100
$$

$$
\begin{aligned}
& \text { Keterangan: } \\
& \mathrm{P}=\text { Persentase } \\
& \mathrm{F}=\text { Frekuensi } \\
& \mathrm{N}=\text { Jumlah Sampel }
\end{aligned}
$$

\section{HASIL DAN PEMBAHASAN PENELITIAN \\ HASIL PENELITIAN}

Motivasi dan persepsi terhadap modifikasi permainan kecil adalah $5 \%$ atau 76 menjawab sangat setuju, $57,57 \%$ atau 875 orang menjawab setuju, 37,24\% atau 556 orang menjawab tidak setuju dan $0,20 \%$ atau 3 orang yang menjawab sangat tidak setuju.

Untuk lebih jelasnya mengenai data-data ini dapat dilihat secara lebih terperinci sesuai dengan indikator penelitian. 
1. Motivasi Siswa Terhadap Penerapan Permainan Kecil

Berdasarkan data penelitian untuk indikator motivasi siswa terhadap 38 orang responden dengan 24 item pertanyaan didapatkan total jumlah pertanyaan sebanyak 912. Untuk lebih jelasnya dapat dilihat pada tabel berikut:

Tabel 1

Distribusi Jawaban Responden Tentang Motivasi Siswa Terhadap Penerapan Permainan Kecil

\begin{tabular}{|l|c|c|}
\hline \multirow{2}{*}{\multicolumn{1}{|c|}{ Alternatif Jawaban }} & Frekwensi dan Persentase Jawaban \\
\cline { 2 - 3 } & $\mathrm{F}$ & $\%$ \\
\hline Sangat Setuju ( SS, nilainya 4 ) & 73 & 8.00 \\
\hline Setuju ( S, nilainya 3 ) & 460 & 50.44 \\
\hline Tidak Seuju ( TS, nilainya 2 ) & 378 & 41.45 \\
\hline Sangat Tidak Setuju ( STS, nilainya 1) & 1 & 0.11 \\
\hline Jumlah & 912 & 100 \\
\hline
\end{tabular}

Dengan melihat tabel di atas, tergambar bahwa responden yang sangat setuju dengan motivasi belajar yang dialaminya adalah sebesar 8\% (73 orang ), setuju sebesar 50,44\% (460 orang), tidak setuju sebesar 41,45\% (378 orang) sedangkan untuk jawaban sangat tidak setuju adalah $0,11 \%$ (1 orang).

2. Modifikasi Ukuran Lapangan

Berdasarkan data penelitian untuk indikator modifikasi ukuran lapangan terhadap 38 orang responden dengan 5 item pertanyaan didapatkan total jumlah pertanyaan sebanyak 190. Untuk lebih jelasnya dapat dilihat pada tabel berikut:

Tabel 2

Distribusi Jawaban Responden Terhadap Modifikasi Ukuran Lapangan dalam Permainan Kecil

\begin{tabular}{|l|c|c|}
\hline \multirow{2}{*}{\multicolumn{1}{|c|}{ Alternatif Jawaban }} & \multicolumn{2}{c|}{ Frekwensi dan Persentase Jawaban } \\
\cline { 2 - 3 } & F & $\%$ \\
\hline Sangat Setuju ( SS, nilainya 4 ) & 3 & 1.58 \\
\hline Setuju ( S, nilainya 3 ) & 154 & 81.05 \\
\hline Tidak Seuju ( TS, nilainya 2 ) & 33 & 17.37 \\
\hline Sangat Tidak Setuju ( STS, nilainya 1) & & 0.00 \\
\hline Jumlah & 190 & 100 \\
\hline
\end{tabular}

Dengan melihat tabel di atas, terlihat bahwa distribusi jawaban responden yang sangat setuju dengan modifikasi ukuran lapangan adalah sebanyak 3 jawaban responden atau 1,58 \%, responden yang setuju dengan modifikasi ukuran lapangan adalah sebanyak 154 orang atau 81,05\%, responden yang tidak setuju sebesar 33 orang atau 17,37\% sedangkan untuk jawaban sangat tidak setuju tidak ada.

3. Modifikasi Peralatan

Berdasarkan data penelitian untuk indikator modifikasi peralatan terhadap 38 orang responden dengan 4 item pertanyaan didapatkan total jumlah pertanyaan sebanyak 152 . Untuk lebih jelasnya dapat dilihat pada tabel berikut: 
Tabel 3

Distribusi Jawaban Responden Terhadap Modifikasi Peralatan dalam Permainan Kecil

\begin{tabular}{|l|c|c|}
\hline \multirow{2}{*}{ Alternatif Jawaban } & Frekwensi dan Persentase Jawaban \\
\cline { 2 - 3 } & F & $\%$ \\
\hline Sangat Setuju ( SS, nilainya 4 ) & & \\
\hline Setuju ( S, nilainya 3 ) & 103 & 67.76 \\
\hline Tidak Seuju ( TS, nilainya 2 ) & 48 & 31.58 \\
\hline Sangat Tidak Setuju ( STS, nilainya 1) & 1 & 0.66 \\
\hline Jumlah & 152 & 100 \\
\hline
\end{tabular}

Dengan melihat tabel di atas, terlihat bahwa distribusi jawaban responden tidak ada yang sangat setuju dengan modifikasi peralatan, responden yang setuju dengan modifikasi peralatan adalah sebanyak 103 orang atau $67,76 \%$ responden yang tidak setuju sebanyak 48 orang atau $31,57 \%$ dan untukjawaban sangat tidak setuju adalah 1 orang atau $0,66 \%$.

4. Modifikasi Lamanya Permainan

Berdasarkan data penelitian untuk indikator modifikasi peralatan terhadap 38 orang responden dengan 4 item pertanyaan didapatkan total jumlah pertanyaan sebanyak 152 . Untuk lebih jelasnya dapat dilihat pada tabel berikut:

Tabel 4

Distribusi Jawaban Responden Terhadap Modilikasi Lamanya Permainan dalam Permainan Kecil

\begin{tabular}{|l|c|c|}
\hline \multirow{2}{*}{ Alternatif Jawaban } & Frekwensi dan Persentase Jawaban \\
\cline { 2 - 3 } & F & $\%$ \\
\hline Sangat Setuju ( SS, nilainya 4 ) & - & - \\
\hline Setuju ( S, nilainya 3 ) & 96 & 63.16 \\
\hline Tidak Seuju ( TS, nilainya 2 ) & 56 & 36.84 \\
\hline Sangat Tidak Setuju ( STS, nilainya 1) & - & - \\
\hline Jumlah & 152 & 100 \\
\hline
\end{tabular}

Dengan melihat tabel di atas, terlihat bahwa distribusi jawaban responden tidak ada yang sangat setuju dengan modifikasi peralatan, responden yang setuju dengan modifikasi peralatan adalah sebanyak 96 orang atau $63,16 \%$ responden yang tidak setuju sebanyak 56 orang atau $36,84 \%$ dan tidak ada responden yang menjawab sangat tidak setuju.

5. Modifikasi Peraturan

Berdasarkan data penelitian untuk indikator modifikasi peraturan terhadap 38 orang responden dengan 3 item pertanyaan didapatkan total jumlah pertanyaan sebanyak 114. Untuk lebih jelasnya dapat dilihat pada tabel berikut: 
Tabel 5

Distribusi Jawaban Responden Terhadap Modifikasi Peraturan dalam Permainan Kecil

\begin{tabular}{|l|c|c|}
\hline \multirow{2}{*}{\multicolumn{1}{c|}{ Alternatif Jawaban }} & Frekwensi dan Persentase Jawaban \\
\cline { 2 - 3 } & F & $\%$ \\
\hline Sangat Setuju ( SS, nilainya 4 ) & - & - \\
\hline Setuju ( S, nilainya 3 ) & 62 & 54.39 \\
\hline Tidak Seuju ( TS, nilainya 2 ) & 51 & 44.74 \\
\hline Sangat Tidak Setuju ( STS, nilainya 1) & 1 & 0.88 \\
\hline Jumlah & 114 & 100 \\
\hline
\end{tabular}

Dengan melihat tabel di atas, terlihat bahwa distribusi jawaban responden tidak ada yang sangat setuju dengan modifikasi peralatan, responden yang setuju dengan modifikasi peralatan adalah sebanyak 62 orang atau 54,39\% responden yang tidak setuju sebanyak 51 orang atau 44,74\% dan untuk jawaban sangat tidak setuju adalah 1 orang atau $0,88 \%$.

\section{PEMBAHASAN}

\section{Motivasi Siswa Terhadap Penerapan Permainan Kecil}

Berdasarkan hasil analisis statistik terhadap data yang diperoleh di SD Negeri 18 Sungai Geringging Kabupaten Padang Pariaman didapatkan persentase motivasi siswa terhadap penerapan permainan kecil dalam pembelajaran pendidikan jasmani olabraga dan kesehatan secara beragam. Untuk persentase respon sangat setuju adalah $8 \%$ dan untuk respon setuju sebesar 50,44\%. Dengan hasil ini, berarti siswa yang termotivasi belajar dengan adanya penerapan permainan kecil dalam pembelajara pendidikan jasmani dan kesehatan adalah sebesar $58,44 \%$.

Untuk persentase respon tidak setuju adalah sebesar $41,45 \%$ dan untuk persentase respon sangat tidak setuju adalah $0,11 \%$. Berarti dan respon siswa didapatkan persentase untuk yang tidak termotivasi belajar dengan adanya penerapan permainan kecil dalam pembelajaran pendidikan jasmani dan kesehatan adalah sebesar $41,56 \%$.

Tinggi rendahnya motivasi siswa dalam sebuah pembelajaran tergantung pada diri siswa sendiri, baik dari dalam diri siswa maupun dari luar diri siswa. Seperti yang diutarakan oleh Syahrul (2008:14) bahwa

"Terpicunya seseorang dalam mengikuti pembelajaran atau suatu kegiatan dapat dipengaruhi oleh unsur intrinsik dan unsur ekstrinsik dirinya”. Unsur intrinsik di sini maksudnya adalah faktor-faktor pendorong atau motivator yang melekat dalam diri seseorang. Seperti kemampuannya, kesehatannya dan kondisi mentalnya.

Selain faktor intrinsik, motivasi siswa juga dipengaruhi oleh faktor ekstrinsik atau faktor luar diri siswa. Menurut Khairuddin (1999:20)ada tiga hal yang mendukung terjadina proses belajar mengajar diantaranya adalah guru sebagai pendidik, siswa sebagai yang akan diajar serta prasarana yang mendukung tercapainya tujuan pembelajaran.

\section{Modifikasi Ukuran Lapangan dalam Permainan Kecil}

Berdasarkan hasil penelitian berupa tanggapan siswa terhadap modifikasi ukuran lapangan didapatkan persentase responden yang menjawab sangat setuju sebesar 1,58\%, setuju 81,05\%, tidak setuju 17,37\%, dan sangat tidak setuju $0 \%$. Dengan demikian yang setuju terhadap modifikasi ukuran lapangan adalah $82,63 \%$ dan yang tidak setuju sebesar $17,37 \%$

Tujuan dalam memodifikasi ukuran lapangan adalah agar siswa tidak terlalu jenuh dalam berolahraga. Hal ini sejalan dengan pendapat Tim Pengajar Sepak Bola FIK UNP (2003) bahwa permainan yang sempit dapat menimbulkan aksi yang sempit, sehingga dalam melakukan permainan, pemain harus mampu berfikir lebih cepat dan kreatif supaya permainan tetap berlangsung dengan seimbang

\section{Modifikasi Peralatan Dalam Permainan Kecil}

Dari responden sebanyak 38 orang dengan jumlah pertanyaan 152 buah, didapatkan persentase jawaban untuk option sangat setuju sebesar $0 \%$, untuk yang setuju sebesar $67,76 \%$, untuk yang tidak setuju sebesar $31,58 \%$, dan untuk option yang sangat tidak setuju sebesar $0,66 \%$. Jadi total keseluruhannya siswa yang setuju terhadap modifikasi peralatan adalah sebesar $67,76 \%$, dan yang tidak setuju terhadap modifikasi peralatan adalah 32,24\%. Dengan demikian dapat ditarik kesimpulan siswa setuju terhadap modifikasi peralatan. 


\section{Modifikasi Lamanya Permainan dalam Permainan Kecil}

Dan responden sebanyak 38 orang dengan jumlah pertanyaan 152 buah, didapatkan persentase jawaban untuk option sangat setuju sebesar $0 \%$, untuk yang setuju sebesar 63,16\%, untuk yang tidak setuju sebesar36,84\%, dan untuk opsion yang sangat tidak setuju sebesar $0 \%$. Jadi total keseluruhannya siswa yang setuju terhadap modifikasi lamanya permainan adalah sebesar $63,16 \%$, dan yang tidak setuju terhadap modifikasi peralatan adalah 36,84\%. Dengan demikian dapat ditarik kesimpulan siswa setuju terhadap modifikasi lamanya permainan.

\section{Modifikasi Peraturan dalam Permainan Kecil}

Dari responden sebanyak 38 orang dengan jumlah pertanyaan 144 buah, didapatkan persentase jawaban untuk option sangat setuju sebesar $0 \%$, untuk yang setuju sebesar 54,39\%, untuk yang tidak setuju sebesar $44,74 \%$, dan untuk option yang sangat tidak setuju sebesar $0,88 \%$. Jadi total keseluruhannya siswa yang setuju terhadap modifikasi peraturan permainan adalah sebesar $54,39 \%$, dan yang tidak setuju terhadap modifikasi peraturan permainan adalah $44,74 \%$. dan untuk option yang sangat tidak setuju sebesar $0,88 \%$. Dengan demikian dapat ditarik kesimpulan siswa setuju terhadap modifikasi peraturan permainan.

\section{KESIMPULAN DAN SARAN \\ KESIMPULAN}

Berdasarkan hasil penelitian dan pembahasannya, dapat ditarik sebuah simpulan tentang permainan kecil dalam pembelajaran penjaskes di SD Negeri 18 Sungai Geringging Kabupaten Padang Pariaman terutama dan segi motivasi siswa, persepsi siswa terhadap modifikasi lapangan, peralatan, lama permainan, dan persepsi siswa terhadap modifikasi peraturan permainan yang diterapkan dalam pembelajaran penjaskes di sekolah yang bersangkutan. Untuk itu berikut dapat dilihat perinciannya:

a. Permainan kecil dalam pembelajaran Penjaskes di SD Negeri 18 Sungai Geringging Kabupaten Padang Pariaman dilihat dari segi motivasi belajar siswa adalah sebesar 58,44\%.

b. Permainan kecil dalam Pembelajaran Penjaskes di SD Negeri 18 Sungai Geringging Kabupaten Padang Pariaman dilihat dari segi persepsi siswa terhadap modifikasi permainan kecil dalam pembelajaran pendidikan jasmani olahraga dan kesehatan dalam hal:

1) Permainan kecil dalam Pembelajaran Penjaskes di SD Negeri 18 Sungai Geringging Kabupaten Padang Pariaman dilihat dari segi modifikasi ukuran lapangan dalam permainan kecil sebesar $81,05 \%$.

2) Permainan kecil dalam Pembelajaran Penjaskes di SD Negeri 18 Sungai Geringging Kabupaten Padang Pariaman dilihat dari segi modifikasi peralatan dalam permainan kecil sebesar 67,76\%.

3) Permainan kecil dalam Pembelajaran Penjaskes di SD Negeri 18 Sungai Geringging Kabupaten Padang Pariaman dilihat dari segi modifikasi lamanya permainan dalam permainan kecil sebesar $63,16 \%$.

4) Permainan kecil dalam Pembelajaran Penjaskes di SD Negeri 18 Sungai Geringging Kabupaten Padang Pariaman dilihat dari segi modifikasi peraturan permainan dalam permainan kecil sebesar $54,39 \%$.

\section{SARAN}

Melihat pada hasil penelitian yang telah dilaksanakan, peneliti mengemukakan saran sebagai berikut:

a) Untuk guru pendidikan jasmani dan kesehatan agar dapat mempedomani hasil penelitian ini untuk meningkatkan pembelajaran pendididkan jasmani olahraga dan kesehatan, terutama di SD Negeri 18 Sungai Geringging Kabupaten Padang Pariaman. Untuk kepala sekolah supaya mengadakan sarana dan prasarana yang memadai untuk meningkatkan pembelajaran siswa SD.

b) Untuk kepala sekolah supaya mengadakan sarana dan prasarana yang memadai untuk meningkatkan pembelajaran siswa SD.

\section{DAFTAR PUSTAKA}

Alimunar. (1993). Diktat Permainan Kecil. Padang: FPOK Padang.

Arikunto. (1993). Dasar-dasar Evaluasi Pendidikan. Jakarta: Bina Aksara. 
Ahmad Thonthowi. (1991). Psikologi Pendidikan. Bandung : Angkasa

Choiri Anwar. 2008. Penggunaan Permainan Kecil Sebagai Salah Satu Cara Menunjang Perkembangan Pisik, Mental dan Intelektual Siswa Usia Sekolah Dasar Tersedia dalam http://www.indoskripsionline./?/ meg=12 (Diakses pada tanggal 07 Oktober 2009)

Hadi, Sutrisno. (1987). Statistik jilid 2. Yogyakarta: Yayasan Penerbitan Fakultas Psikologi UGM.

Mudjiran, dkk. (2003)- Perkembangan Peserta Didik. Padang: Tim MXDK HP Padang UNP.

Muhajir, dkk. (2004). Pendidikan Jasmani. Bandung: Erlangga.

Slameto. (1991). Belajar don Faktor yang Mempengaruhinya. Jakarta: Rineka Cipta

Soemitro. 1992. Permainan Kecil. Dikbud: Dirjen Pendidikan Tinggi Proyek Pembinaan Tenaga Pendidik

Soeningrat. 1984. Teori Permainan. Yogyakarta: Yayasan Sekolah Tinggi OlahRaga

Surnardjati. 2005. Meningkatkan Kemampuan Menyelesaikan Soal Cerita Pokok Bahasan Pecahan Melalui Diskusi Kelompok. Tersedia dalam http// www. Corn. Online./?/meg (Diakses pada tanggal 5 April 2009)

Winarno. (1992). Pengantar Penelitian Ilmiah Dasar Metode Dan Taktik. Bandung: Tarsito 